\title{
Science Teacher Candidates' Skills to Ensure Method-Material Harmony and Integration
}

\author{
Davut Saritaş \& Emin Tamer Yenen \\ Nevşehir Hacı Bektaş Veli University, Education Faculty, Nevşehir, TURKEY
}

Received: 6 February 2020 - Accepted: 5 May 2020 • Published Online: 15 May 2020

\begin{abstract}
In this study, it was aimed to determine the harmony and integration levels of the material prepared by the science teacher candidates with the methodical approach they adopted. In this case study, the data was obtained from observations of material practices and documents introducing the materials. In the study of 41 teaching materials prepared by $3^{\text {rd }}$ grade teacher candidates prepared at different levels considering the achievements of the Science curriculum, the data were analyzed by descriptive analysis, content analysis and the "methodological approach-material integration level" rubric developed by the researchers. In the findings it was determined that although teacher candidates design materials in three different categories in accordance with three different teaching approaches of science (discovery learning; inductive reflective materials, expository teaching; direct reflective materials, research method; multiple systematic reflective materials), they mostly use materials with inappropriate methodological approaches and low level of integration during the application process.
\end{abstract}

Keywords: science education, teaching method, teaching material, learning environment, teacher training undergraduate program.

\section{Introduction}

In the paradigm based on the constructivist learning theory that has become dominant in today's educational understanding, learning is based on the individual's own experiences and experiences (Bodner, 1986; Hand \& Treagust, 1991). It is known that teaching environments that enable the active learning of individuals provide more efficient educational results (Açıgöz, 2003). Therefore, the quality of learning depends on the learning environment primarily. The ideal learning environment is an environment where learning takes place at the highest level and there are regulations supporting learning (Zedan, 2010). While organizing an ideal learning environment, many factors such as thermal comfort, light, class objects, ventilation, technical equipment and teaching materials should be considered (Basque \& Dare, 1998; Yenen \& Dursun, 2018).

The essence of using teaching material is to facilitate the teaching and learning process. However, these materials should be prepared for the purpose of the teaching process by making reasonable estimates about how individuals learn, not as a decoration tool in the classroom (Amadioha, 2009). A purposefully and correctly prepared teaching material can be used for purposes such as drawing attention in the classroom environment, transferring information, giving clues about the subject, ensuring class participation, repeating what is learned, giving

(C) Authors. Terms and conditions of Creative Commons Attribution 4.0 International (CC BY 4.0) apply. Correspondence: Emin Tamer Yenen, Nevşehir Hacı Bektaş Veli University, Education Faculty, Nevşehir, TURKEY. E-mail: tameryenen@gmail.com. 
feedback and making corrections and assessments (Şahin \& Ylldırım, 2004). Kablan, Topan and Erkan (2013) conducted a meta-analysis of the research on the use of materials. In their study benefits of materials used in teaching environment are listed as: facilitating learning, increasing interest and desire, providing active learning, supporting individual learning, providing real-life learning experiences, and developing critical thinking, problem solving and creativity skills. Among the results of the same study, it was seen that science education was one of the most effective results obtained areas of material use.

- Science teacher candidates designed teaching materials in three different categories in accordance with three different teaching approaches (Discovery approach; Inductive Reflective Materials, Expository approach; Direct Reflective Materials, Research approach; Multiple Systematic Reflective Materials).

- The materials designed by teacher candidates were mostly used with inappropriate methodological approaches and low level of integration.

- In the study, an indicators list of suitability of science teaching materials to teaching approaches and a rubric that can be used to evaluate the levels of teaching approach-material integration were developed.

Organizing learning environments, an important component of effective classroom management, is one of the most valuable teaching skills that prospective teachers must acquire (Woodcock \& Rupert, 2012). Within the General Competencies of Teaching Profession published by the Ministry of National Education (MNE) (2017), a competence statement was given as "prepares material suitable for the acquisitions under the title of competence to create learning environments which is one of the competences in the professional skills category." Therefore, considering the ability to prepare and use materials appropriate to the subject area and the needs of the students in creating effective learning environments, it is important for teachers to integrate qualified materials with the right methods and techniques in terms of the quality of teaching. The quality of teaching materials, teaching methods and techniques, the professional competencies of teachers determine the quality of the learning environment (Smith \& Ragan, 2004; Yanpar, 2006). In other words, the trio of teachers, methods and materials are the main components of a good learning environment. Well-trained teachers need to be able to use appropriate teaching methods and techniques and appropriate teaching materials. Therefore, the undergraduate programs prepared for teacher training should include knowledge and skills for preparing instructional material and use of teaching methods.

In this respect, in Turkey in the Undergraduate Science Teacher Training Program, methods used in science education are taught in the content of Special Teaching Methods courses, on the other hand, the content focusing of material in teaching was taught within the scope of Instructional Technology and Material Design course (Council of Higher Education, CEH, 1997). However, the name of this course was changed to "Instructional Technologies" in the 2018 program. In addition, Design of Materials in Science Teaching course, which is an elective domain education course for instructional materials, was also included in the program (CEH, 2018). When both programs are compared, the following points draw attention in this context:

(1) In both programs, courses on teaching materials are given before the courses on domain-specific teaching methods.

(2) While there is no emphasis to "domain-specify" in previous program, "domainspecify" is frequently emphasized not only on the basis of methods and techniques but also on material design in the new program $(\mathrm{CEH}, 2018)$. When comparing the old program updated in 2007 and the new program updated in 2018, the following points draw attention in this context: 
- In Teaching Practice I and II courses: "Making observation regarding domainspecific methods and techniques; making micro-teaching practices by using domainspecific teaching methods and techniques";

- In Teaching Technologies course: "Creating a storehouse of domain-Specific objects";

- In Material Design in Science Teaching course: "Domain-specific technological tools and materials (simulations, animations, virtual classrooms and laboratory environments, concept cartoons, scientific measurement tools, worksheets, slides, visual media tools, etc.) and other information Technologies (web 2.0 tools, mobile applications, student response systems, learning management systems, augmented reality applications, measurement and evaluation tools, etc.) that can be used in science education, classroom environments in which technology is integrated, interactive boards and training portals; using and developing domain-specific information technologies in science teaching."

It is remarkable that the domain-specificity is emphasized especially in Teaching Practice courses. This is an indication that use of domain-specific methods and techniques and the development of domain-specific materials is foreseen as a gain and competence in the future for prospective teachers. Because the development of positive attitude in science teaching depends on the methods and techniques used in the courses. One of the techniques that can be used in science teaching is to use material specific to the field (Ünal, Akıncı \& Şahin, 2000).

In the literature, it is seen that a lot of research has been done on the instructional technologies and material design in the previous programs (Cabı \& Ergün, 2016; Çalışoğlu, 2015; Duman, 2013; Özcan \& Koştur, 2019; Özer \& Tunca, 2014; Yanpar, Koray, Parmaksız \& Arslan, 2006; Yelken, 2009). The results obtained from these studies show that this course generally improves the material design skills of prospective teachers. Although the design skills of the material are an important dimension, it is not an adequate dimension. Sufficient integration of a designed material into a suitable methodological approach is also important. As a matter of fact, teachers should consider the suitability of these materials for teaching objectives, teaching methods, students' characteristics and teaching environment while using educational tools (Yalın, 2004). From this point of view, when the science education literature is examined, no study focusing on the domain-specific teaching methods and material integration is found. In this respect, studies on domain-specific material and method integration can fill a gap. In this general framework, the skills of prospective teachers who do not receive a direct training on how to ensure the integration of methods and materials are worth investigating.

\subsection{Purpose and research questions}

In this study, it was aimed to investigate the science teacher candidates' teaching material application processes in terms of the quality of the prepared material, preferred methodological approach and method-material compatibility. In line with this purpose, answers to the following questions were sought:

(1) What are the methodological approaches that prospective teachers prefer in their material application processes?

(2) How is the harmony between the materials prepared by the prospective teachers and the methodological approach they prefer in terms of the structural properties of the materials?

(3) How is the harmony between the materials prepared by the prospective teachers and the methodological approach they prefer? 


\section{Method}

For the purpose of the research, it was decided that the most appropriate qualitative research pattern for this study, which has a qualitative nature, is a case study. According to Yin (2003), case study is a research method that examines a case, which is expressed as a case in qualitative research, in the context in which it is used, when more than one source of evidence or data is available. The cases examined in case studies may show structural differences expressed through research problems. Therefore, there are different examination patterns (Ylldırım \& Şimşek, 2005: 290). Considering the research questions, it is seen that this study is oriented towards a holistic situation with different dimensions in the focus of the teaching material, such as the materials prepared by a certain group of prospective teachers, the methodological approaches they prefer in these material applications, and the nature of the materials in this methodological approach. For this reason, the preferred pattern is the Nested Single State Pattern.

\subsection{Participants and procedure}

The study was carried out with 41 pre-service teachers studying at the third grade in the Science Education program at a public university in Central Anatolia. The research was carried out within the scope of the Instructional Technologies and Material Design course conducted in accordance with the content defined by $\mathrm{CEH}$ (2007) (Appendix-1) in the fall semester of the 2017/2018 academic year. In accordance with the course content during the application hours of the course, in line with the principles of material development all participants were asked to take into account the subject areas and objectives given in the Science Education program (MNE, 2018) which was renewed. Objectives were selected from different science fields (chemistry, biology, physics, climatology, astronomy etc.) and different grade levels. Since there is no content that directly gives specific/general teaching methods to the scope of the course, no guidance or guidance was provided to the participants in introducing the methodological approaches to be preferred in the material application process. No evaluation and feedback has been made during the process. However, in order to examine the material application process in more detail, they were asked to make a plan that introduces the application and accordingly, before the application, each student was asked to prepare a presentation introducing the material prepared and containing information on how to use it in the lesson.

The process is as follows:

(1) Giving theoretical information (4 weeks);

(2) Time for participants to develop materials (7 weeks);

(3) Collection of material application reports and presentations (at week 7);

(4) Material applications (7 weeks);

(5) Sharing the material evaluations with the participants (in the $14^{\text {th }}$ week).

\subsection{Data collection}

In accordance with the nature of the case study, the data in this study were provided from two sources: observations and documents.

\subsubsection{Observations}

Starting from the $7^{\text {th }}$ week of the research process, each participant introduced his material first and then carried out the application he planned for the use of the material in the 
classroom. These applications were observed through a semi-structured observation form. The observation form contains three dimensions depending on the research problems. These are: the methodical approach preferred by the participant in practice, the structural properties of the material, and the status of the material in the process.

\subsubsection{Documents}

In the $7^{\text {th }}$ week of the research process, application plans collected from the participants and presentation files used in the applications were used as data sources. These documents were prepared by the participants through a semi-structured framework, where the participants were previously given. This framework includes the following dimensions: the relevant learning outcomes of the material, the process of making the material, its physical properties, its use in the teaching process, expectations of external learning outcomes from the material and subjective evaluation.

\subsection{Data analysis}

Data analysis was carried out in three stages depending on research problems.

\subsubsection{Methodological approach in material applications}

In the observations and documents belonging to each participant, the data regarding the application processes of the materials were analyzed descriptively in terms of the methodological approach adopted in the application process. In descriptive analysis, themes were determined by taking into account the teaching strategies (Güneş, 2014) classified according to the cognitive learning approach in the literature, and the different methods and techniques (Özden, 2000) expressed under these strategies were taken as sub-themes. In this way, which strategy is appropriate for the participant's methodical approach was determined, and methodological approach in accordance with three themes was determined: application through expository, application through discovery, and application through research.

\subsubsection{Nature of material-method integration}

At the end of the first stage, the methodological approach used in the application of the materials prepared by each participant was determined. At this stage, the harmony of the material with this approach was examined. In the literature, evaluation criteria specific to readymade teaching materials are mentioned in general (e.g., Seferoğlu, 2006). However, no criteria were found to be used both in evaluating the relationship between a material and the method in general, or in terms of evaluating science materials in general. Therefore, for the purpose of the study, in order to make an evaluation in terms of the harmony of the materials used with the preferred methodological approaches expert opinions were consulted. Interviews were held with five experts, including two educational sciences and three science education experts. The experts were asked two main questions: (1) what should be considered in the use of materials for instructional strategies? (2) which strategy and which materials should be preferred? In this context, harmony is dealt with in two aspects. 
D. Saritaş \& E. T. Yenen - Science Teacher Candidates' Skills to Ensure Method-Material...

2.3.3 Determination of the suitability of the materials to the method in terms of structure

In line with the opinions obtained from semi-structured interviews with experts, firstly, indicators were revealed for the structural features that should be in a material suitable for each strategy.

Table 1. Methodological approach and appropriate material indicators

\begin{tabular}{ll}
\hline $\begin{array}{l}\text { Methodological } \\
\text { Approach }\end{array}$ & Structural Main Indicators of Appropriate Materials \\
\hline Expository & $\begin{array}{l}\text { Direct reflective materials; structured materials that have a } \\
\text { physical integrity, that directly reflect information to students, that } \\
\text { students can use individually, or that the teacher himself can use. For } \\
\text { example, fixed or moving models, banners, ready concept maps, } \\
\text { diagrams, maps, etc. }\end{array}$
\end{tabular}

Discovery

Inductive reflective materials; unstructured materials, which are made up of different parts and do not give a specific message alone, which should be brought together inductively and by using certain rules, thus revealing the message, allowing students to experience with the group. For example; play and activity sets, concept map components, open-ended worksheets, etc.

\title{
Research
}

\begin{abstract}
Multiple systematic reflective materials; It refers to a cluster formed by combining objects that are either a kind of material in their own right or prepared as a material for a particular purpose. It is a sophisticated / multi-material material that can be used together in a systematic form, and allows flexible use, which allows to link different messages with each other. They allow students to experience and use individually or with a group. For example, the combination of materials in the first two groups.
\end{abstract}

In all observation data and documents, content analysis was conducted by coding the information about the material, taking into account the indicators described above. In this way, the material type of each participant was determined.

2.3.4 Determination of the level of harmony of the materials with the method in terms of usage

In line with expert interviews, a rubric containing material adaptation assessment indicators and levels focused on methodological approach was prepared. Stages such as listing criteria, determining performance levels and obtaining expert opinions were taken into consideration in the preparation of rubrics (Goodrich, 2001). After the validity and reliability studies of the prepared rubric were completed, the data of each participant, which was classified in terms of methodological approach and material quality, were evaluated through this rubric. In this way, the harmony level of the materials to the methodological approach was determined. 
Table 3. Material integration levels in methodological approaches

\begin{tabular}{|c|c|c|c|}
\hline \multirow[t]{2}{*}{ Dimensions } & \multicolumn{3}{|c|}{ Material Integration Levels and Indicators } \\
\hline & High & Moderate & Low \\
\hline $\begin{array}{l}\text { Materials in } \\
\text { Discovery } \\
\text { Approach }\end{array}$ & $\begin{array}{l}\text { Using knowledge with student } \\
\text { participation in all stages of the } \\
\text { discovery process and evaluation / } \\
\text { repetition (sampling, determining } \\
\text { relationships, generalizing, } \\
\text { deepening, transferring and } \\
\text { testing etc.) }\end{array}$ & $\begin{array}{l}\text { Using with student } \\
\text { participation at } \\
\text { some stage of the } \\
\text { discovery process }\end{array}$ & $\begin{array}{l}\text { Using in the process } \\
\text { of repeating or } \\
\text { evaluating of } \\
\text { information }\end{array}$ \\
\hline $\begin{array}{l}\text { Materials in } \\
\text { Expository } \\
\text { Approach }\end{array}$ & $\begin{array}{l}\text { Using information in all stages of } \\
\text { the expository process and } \\
\text { evaluation / repetition } \\
\text { (identification, sampling and } \\
\text { referring to new examples, etc.) }\end{array}$ & $\begin{array}{l}\text { Using information } \\
\text { at a stage of the } \\
\text { expository process }\end{array}$ & $\begin{array}{l}\text { Using information in } \\
\text { the stage of evaluation } \\
\text { and repetition }\end{array}$ \\
\hline $\begin{array}{l}\text { Materials in } \\
\text { Research-Based } \\
\text { Approach }\end{array}$ & $\begin{array}{l}\text { Using with student participation } \\
\text { in all stages of the question / } \\
\text { problem solving process and } \\
\text { evaluation / repetition } \\
\text { (determining the question, } \\
\text { defining the question, suggesting } \\
\text { solutions, etc.) }\end{array}$ & $\begin{array}{l}\text { Using with student } \\
\text { participation at one } \\
\text { stage of the } \\
\text { question / problem } \\
\text { solving process }\end{array}$ & $\begin{array}{l}\text { Using in the process } \\
\text { of repeating or } \\
\text { evaluating of } \\
\text { information }\end{array}$ \\
\hline
\end{tabular}

\subsection{Validity and reliability}

Validity and reliability studies (Creswell, 2014; Miles \& Huberman, 2014) such as expert review, data diversification, participant confirmation, independent coding suggested in qualitative research at the stages of this study were carried out as follows:

(1) During the data collection process; parallel observations were made by two researchers, observation data were compared, harmonized and integrated. Expert opinion was received in the structuring of the application reports prepared by the participants. On the other side, data collection was also been diversified.

(2) During the analysis process; in descriptive and content analysis, some of the data (data from 10 participants) were analyzed by an independent analyst, and a harmony between categories and themes was provided by researchers' analyzes. Besides, since the codes were obtained from the interviews with the experts in the content analysis, the prepared codes were confirmed to the experts. On the other hand, the methodological approach-material integration level prepared based on the information obtained from expert interviews was tested on the data of 5 participants the rubric. The results of the evaluation were compared with the expert evaluations made without rubric and the indicator of "using in repetition" was added to the low level. Rubric took its final form after the confirmation of the experts interviewed.

\section{Results}

After the descriptive analysis of the data, since there is no reference or behavior corresponding to certain teaching methods in the material applications and expressions of the participants, the methodological approaches are limited to the strategy level in order to protect the objectivity of the analysis. These are as follows; application by expository, application by discovery; application through research. The quality of material-method integration under the 
D. Saritaş \& E. T. Yenen - Science Teacher Candidates' Skills to Ensure Method-Material...

titles linked to these preferred methodological approaches is given in the light of tables and data quotes.

3.1 Materials in expository teaching approach

Table 3. Materials in expository approach

\begin{tabular}{cccc}
\hline & \multicolumn{3}{c}{ Integration Level to Methodological Approach } \\
\cline { 2 - 4 } Material Class & High & Moderate & Low \\
\hline $\begin{array}{c}\text { Direct reflective } \\
\text { materials }\end{array}$ & - & - & M23-M41-M31 \\
\hline $\begin{array}{c}\text { Inductive reflective } \\
\text { materials }\end{array}$ & M7-M11 & M6-M22-M27-M36-M5- & M19-M21-M24 \\
\hline $\begin{array}{c}\text { Multiple systematic } \\
\text { reflective materials }\end{array}$ & M26 & - & $\mathrm{M} 3$ \\
\hline
\end{tabular}

The most preferred methodical approach for participants in the material application process is the way of expository $(\mathrm{N}=22)$. When the materials used with this approach are analyzed, it is seen that inductive reflective materials are more. However, the integration levels of these materials with the method are mostly low.

For example, the statements of the participant regarding the use of such a material (M16, Appendix-2) prepared on Foods are as follows:

"Our material will be used for the $5^{\text {th }}$ grade, after the subject is explained and 6 people will be selected from the students and each will be given cards. Then each student will choose four of the envelopes of vitamins... in this way, they will remember what they have learned before in the lesson."

Material 16 was used as a reminder after the subject was traditionally processed. On the other hand, according to expert opinions, most of the direct reflective materials that are suitable for this methodological approach are at the low integration level. For example, the statements regarding the usage process of a participant who prepared such a material for the subject of the Circulatory System are as follows (M33, Appendix-3):

"After the lecture, students can use the material without teacher assistance. The student's interest in the subject increases. The permanence of the subject is increased."

On the other hand, it is seen that two of these materials are sufficiently integrated into this approach, to which they are compatible. For example, the participant's statements (M2, Appendix-4) regarding a material prepared on the Digestive System are as follows:

"The material is designed to be used throughout the lesson. While the lesson is being processed, the students are provided with the figure to see which foods are exposed to which organs and what kind of digestion... In order to see this, they have to come and open the boxes on the model. In this way, their participation in the lesson increases as well. In the evaluation of the end of the lesson, the window in the brain of the human figure opens. This window contains pictures of nutrients (carbohydrates, fat, protein) placed upside down. Asking where these foods begin digestion and what type of digestion they are required to be adhered to the relevant organ. The nutrients here can be increased according to the class size." 
3.2 Materials in discovery learning approach

Table 4. Materials in discovery approach

\section{Integration Level to Methodological Approach}

$\begin{array}{llll}\text { Material Class } & \text { High } \quad \text { Loderate }\end{array}$

\begin{tabular}{llll}
\hline $\begin{array}{l}\text { Direct reflective } \\
\text { materials }\end{array}$ & M2-M20 & M1-M18-M29-M34 & M33-M35-M32-M30 \\
\hline $\begin{array}{l}\text { Inductive reflective } \\
\text { materials }\end{array}$ & - & - & $\begin{array}{l}\text { M4-M8-M12-M15-M16-M17- } \\
\text { M25-M28-M37-M38-M39-M9 }\end{array}$ \\
\hline
\end{tabular}

\section{Multiple systematic reflective materials}

Another methodical approach preferred by the participants in the material application process is the way of invention $(\mathrm{N}=16)$. The category of material that is compatible with this approach in line with expert opinions is inductive reflective materials. As seen in the table, inductive reflective materials are more. The level of integration of such materials with the method is mostly moderate, but there are also lower ones.

The statements of a participant about a material related to the Creatures and Life subject (M5, Appendix-5) used at the moderate level of integration are as follows:

"The material is designed to be used during the lesson. What is expected from the material is to attract the attention of the student and to grasp the subject. On the other hand, as the puzzle activity continues and the puzzle is completed, students will realize that a whole is made up of parts, they will perceive that their living spaces form a whole and that everything in nature is one of those parts, they will deduce how important individuals are."

The participant statements regarding the material prepared for the topic of Creatures and Life (M7, Appendix-6), which have achieved high level of integration, are as follows:

"The first part of our material will be used when explaining the lesson, and the second part will be used at the end of the lesson. In this way, the first part allows students to see the parts, differences and properties of the cell by sensing them and to understand them. The second part allows both evaluation and deduction of organelles' new duties... Increases the power of thinking. They learn to work in a group and trust their group. Students will be asked each other to perceive their friends by asking questions, and their communication with their friends increases. It enables students to actively participate in the lesson."

In the direction of expert opinions, two examples of multiple systematic reflective materials, which are not primarily recommended for the discovery approach, are encountered in this approach. The participant statements regarding a material (M26, appendix- 7) for Physical and Chemical Changes that have achieved high integration with the discovery approach are as follows:

"While explaining the concepts of physical and chemical change, the teacher explains the differences between the particle structure of physical and chemical change by using this material as well as the definition. However, he wants them to guess how the particles of matter can be after the change on the ground and make them with play dough. The teacher does the same in chemical change. He then directs it to the right shapes with directions. He allows students to define physical 
D. Saritaş \& E. T. Yenen - Science Teacher Candidates' Skills to Ensure Method-Material...

and chemical change... then uses other material (bottle game) to recognize these changes in our environment through questions."

It is seen that different types of materials with low integration are generally used for evaluation or repetition at the end of the lesson. Although the planning of the course is presented based on the discovery, the use of these materials is left to the end of the course.

\subsection{Materials in research approach}

Table 5. Materials in research approach

\section{Integration Level to Methodological Approach}

$\begin{array}{llll}\text { Material Class } & \text { High } & \text { Loderate }\end{array}$

\begin{tabular}{llll}
\hline $\begin{array}{l}\text { Direct reflective } \\
\text { materials }\end{array}$ & - & - & - \\
\hline $\begin{array}{l}\text { Inductive reflective } \\
\text { materials }\end{array}$ & - & M13 & - \\
\hline
\end{tabular}

$\begin{array}{ll}\text { Multiple systematic } & \text { M40-M14 - } \\ \text { reflective materials }\end{array}$

Another method which is rarely preferred by participants during the material application process is the research method $(\mathrm{N}=3)$. The category of material that is compatible with this approach in line with expert opinions is multiple systematic reflective materials. When the table is examined, it is seen that only two materials are used in this approach at the level of high integration.

For example, the participant statements about such a material (M14, Appendix-8) prepared for the Transmission of Electricity are as follows:

"Before the lesson, students will be asked to bring the items to be used in the construction of a part of the material with an assignment to be given to the students. Using these, the sub-part of the material (rail) will be created. The aim will be to investigate which materials transmit electricity. Students will be made to make predictions about whether the items, which are brought before the material is fully constructed, are conductive or insulating. Students will be asked about how to test them. Then, the first part that I prepared and the second part will be combined and tests will be made on the material. In the course of the lesson, by providing students to explain, interpret and draw conclusions from these observations, we enable students to make predictions, to make observations, to interpret the data obtained and to draw conclusions, in other words, to gain scientific process skills. With this simple and at the same time useful material we have prepared, students have the opportunity to control and experiment by changing variables. Their imagination develops. Since each group prepares their own materials, their self-confidence increases. It provides cooperation and solidarity. It makes the lesson interesting."

Other suitable material (M40, Appendix-9) is similarly made by students through research. On the other hand, it is seen that an inductive reflective material is used with moderate integration in this approach. The data excerpt about the use of this material, prepared on Electricity Transmission and Physical Events (M13, Appendix-10) is as follows:

"In order to prepare for the lesson, it is ensured to research whether the electricity is always transmitted in the same way. Some students are given the historical story 
of electricity as a subject of research. Students are asked to prepare a presentation on this subject. Then, students are asked to fill the concepts in the information treasure box with their prior knowledge. Students then make predictions about which conductors are better conductors, on the conductor wheel. Finally, students can be shown the variables to which the bulb is connected in the simple electrical circuit. Factors affecting the conductivity are supported with examples from our daily life. At the end of the lesson, the images and questions in the Predict and Write box are gathered, new examples are discuss."

\section{Discussion}

The results obtained in this study can be summarized as follows; teaching materials prepared by science teacher candidates are divided into three different categories in accordance with three different teaching approaches. In this context, the materials are classified as follows; Inductive Reflective Materials suitable for the discovery approach, Direct Reflective Materials suitable for the expository approach, and, on the other hand, Multiple Systematic Reflective Materials suitable for the research approach. However, when looking at the application processes of the prepared materials, some problematic situations manifest themselves. Firstly, it is seen that the participants draw attention to carry out material applications without emphasizing a specific or general teaching method, and their methodological approaches remain at the strategy level. Secondly, most of the materials are not used with a methodical approach which is determined to be essentially appropriate. Another is the low integration of those used with the appropriate methodological approach into the teaching process. For example, Inductive Reflective materials in accordance with the discovery approach are applied by expository approach and are integrated at a low level in the process. In this way, it is seen that the potential of a quality material which is suitable for a more effective teaching strategy in science education is not transferred due to the wrong approach and wrong positioning in the process (e.g., at the end of the lesson). A similar situation is observed directly in reflective materials. Although these materials are suitable for the expository approach by their nature, they have been applied through the discovery approach and their integration has been low. On the other hand, although Multiple Systematic Reflective materials which are suitable for the research approach are very few, adaptation and integration problems have also been observed in this approach.

Considering the literature in the light of the results obtained within this framework, there are many theoretical and practical studies focused on topics; the process of developing teaching materials in general terms, the importance of the materials, their contribution to the teaching process and learning, teachers' level of using materials, their views on teaching materials, their creativity in developing materials, etc. (Çiftçi, Yıldız \& Bozkurt, 2015; Fidan, 2008; İşman, 2003; Duman, 2013; Özer \& Tunca, 2014; Yanpar, Koray, Parmaksız \& Arslan, 2006; Yelken, 2009; Saritas \& Polat, 2017; Kahyaoglu, 2011; Kazu \& Yesilyurt, 2008). Despite the fact that there are unique studies about the frequency of science teachers' use and utilization of materials (Karamustafaoğlu, 2006), examination of the materials, which are produced by science teacher candidates, in terms of content messages and the items used (Özcan \& Koştur, 2019), no studies on the integration of the methodologies and materials were encountered. In this respect, it can be said that the study results are quite original. Although there is no literature to compare study results, a theoretical evaluation of the results can be made.

When teachers use educational tools, they should consider the suitability of these materials for teaching objectives, teaching methods, students' characteristics and the teaching environment (Yalın, 2004). Therefore, in this study, the course taken by participant science teacher candidates can be expected to gain these skills. Studies on this course have shown that in many respects, prospective teachers contribute to their skills in developing and using materials (Çalışoğlu, 2015; Cabı \& Ergün, 2016; Bozpolat \& Arslan, 2018; Bektaş, Nalçacı \& Ercoşkun, 2009; 
Gömleksiz, Kan \& Serhatlığlu, 2010; Güven, 2006; Saka \& Saka, 2005). However, there is no evidence or emphasis on teaching method-material harmony and integration in the related literature. On the other hand, there is no response in this regard in the content of this course $(\mathrm{CEH}$, 2007). In addition, although the prospective teachers who have prepared the materials are $3^{\text {th }}$ grade students and have received a general education on methods (e.g., teaching principles and methods) within the scope of professional knowledge courses in previous years, the lack of such a dimension in the content of these professional knowledge courses can be considered as a reason of the lack of method-material harmony. The result obtained in the study shows that prospective teachers do not have the knowledge that they can associate the materials specific to the domain with a suitable method.

\section{Conclusion}

Consequently, considering the undergraduate programs (CEH, 2007; 2018) in which science teacher candidates are studying, there is no clear educational content regarding methodmaterial integration. When the material application plans and application processes prepared by the participants for certain acquisitions are examined, method and material integration emerges as a problem. For this reason, it seems necessary to provide prospective teachers with training on the qualifications of domain-specific materials and their "skills" to ensure their harmony and integration with current methods. Science education is the domain that has relatively the most effective results in using materials. In order to increase this potential of science education, adding an elective course on method-material integration to undergraduate programs can be offered as a basic suggestion.

\section{Acknowledgements}

This research did not receive any specific grant from funding agencies in the public commercial, or not-for-profit sectors.

The authors declare no competing interests.

\section{References}

Açıkgöz, Ü. K. (2003). Aktif öğrenme [Active learning]. İzmir: Eğitim Dünyası Yayınları.

Amadioha, S. W. (2009). The importance of instructional materials in our schools: An overview. New Era Research Journal of Human, Educational and Sustainable Development, 2(3), 61-63

Basque, J., \& Dare, S. W. (1998). Environment and apparatuship information. Journal of Distance Education, 13(1), 626-638.

Bektaş, F., Nalçacı, A., \& Erçoşkun, H. (2009). Classroom teacher candidates' views on the attainments from "Teaching technologies and material development" Course. Journal of Theoretical Educational Science, 2(2), 19-31.

Bodner, G. M. (1986). Constructivism: A theory of knowledge. Journal of Chemical Education, 63(10), 873878.

Bozpolat, E., \& Arslan, A. (2018). Preservice teachers' views about the course teaching technologies and material design, E-International Journal of Educational Research, 9(3), 60-84, https://doi.org/10.19160/ijer.463977 
Cabı, E., \& Ergün, E. (2016). The impact of instructional technologies and material development course on the teacher candidates' concern about using educational technologies. Başkent University Journal of Education, 3(1), 37-43.

Çalışoğlu, M. (2015). Opinion of preservice elementary teachers about the instructional technologies and material development course. Current Research in Education, 1(1), 23-32.

CEH (1997). Science education, education faculty teacher training undergraduate programs. Retrieved from: https://www.yok.gov.tr/Documents/Yayinlar/Yayinlarimiz/egitim-fakultesi-ogretmenyetistirme-lisans-programlari-mart-1998.pdf.

$\mathrm{CEH}$ (2007). Education faculty teacher training undergraduate program. Retrieved from: https://www.yok.gov.tr/Documents/Yayinlar/Yayinlarimiz/egitim-fakultesi-ogretmenyetistirme-lisans-programlari-mart-1998.pdf.

CEH (2018). Teacher training undergraduate programs. Retrieved from: https://www.yok.gov.tr/kurumsal/idaribirimler/egitim-ogretim-dairesi/yeni-ogretmenyetistirme-lisans-programları.

Çiftçi Ş, K., Yıldız P., \& Bozkurt, E. (2015). Middle school mathematics teachers' opinions about using material. Journal of Educational Policy Analysis, 4(1), 79-89.

Creswell, J. W. (2014). Research design: Qualitative, quantitative, and mixed methods approaches ( $4^{\text {th }}$ Ed.). Thousand Oaks, CA: Sage Publications.

Duman, G. B. (2013). Material development and effective use of materials in teaching Turkish as a foreign language. Journal of Mother Tongue Education, 1(2), 1-8.

Fidan, N. K. (2008). Teachers' views with regard to the use of tools and materials in the primary level Journal of Theoretical Educational Science, 1(1), 48-61.

Gömleksiz, M., Kan, A., \& Serhatlığlu, B. (2010). Prospective teachers' opinions about the effectiveness of instructional technology and material development course to have them acquire principles of material preparing. Electronic Journal of Social Sciences, 9(32), 1-16.

Goodrich, A. H. (2001, April 17). The effects of instructional rubrics on learning to write. Current Issues in Education, 4(4).

Güneş, F. (2014). Öğretim ilke ve yöntemleri [Teaching principles and methods]. In F. Güneş (Ed.), Öğretim stratejileri [Teaching strategies] (pp. 61-77). Ankara: Pegem Akademi.

Güven, S. (2006). The evaluation of teaching technologies and materials development course in terms of competencies it provides (a sample of Inönü Unıversity faculty of education). The Journal of Turkish Educational Strategies, 4(2), 165-179.

Hand, B., \& Treagust, D. F. (1991). Student achievement and science curriculum development using a constructivist framework. School Science and Mathematics, 91(4), 172-176.

İşman, A. (2003), Öğretim teknolojileri ve materyal geliştirme [Instructional technologies and material development]. İstanbul: Değişim Yay.

Kablan, Z., Topan, B., \& Erkan, B. (2013). The effectiveness level of material use in classroom instruction: A meta-analysis study. Educational Sciences: Theory \& Practice, 13(3), 1629-1644.

Kahyaoğlu, M. (2011). The views of elementary teachers on using new technologies in science and technology teaching. EBAD-JESR, 1(1), 79-96.

Karamustafaoğlu, O. (2006). Science and technology teachers' levels of using instructional materials: Amasya sample. Journal of Bayburt Education Faculty, 1(1), 190-101.

Kazu, H., \& Yeşilyurt, E. (2008). Teacher's aims of using instructional tools and materials. Firat University Journal of Social Science, 18(2), 175-188.

Miles, M., \& Huberman, A. (2014). Qualitative data analysis (2 ${ }^{\text {nd }}$ Ed.). London: Sage Publications. 
D. Saritaş \& E. T. Yenen - Science Teacher Candidates' Skills to Ensure Method-Material...

MNE (2017). İlköğretim kurumları fen bilimleri dersi öğretim programı [Science education curriculum of primary education institutions]. Ankara: Talim ve Terbiye Kurulu Başkanllğı.

MNE (2017). General Competencies of Teaching Profession. Retrieved from: http://oygm.meb.gov.tr/meb_iys_dosyalar/2017_12/11115355_YYRETMENLYK_MESLEYY GENEL YETERLYKLERY.pdf

Özcan, H., \& Koştur, H. İ. (2019). Analyzing pre-service science teachers' physics materials. Science Education International, $30(1)$.

Özden, Y. (2000). Öğrenme ve öğretme [Learning and teaching] (8 $8^{\text {th }}$ ed.). Ankara: Pegem Yayıncılık.

Özer, Ö., \& Tunca, N. (2014). The opinion of pre-service teachers towards preparing and using of materials. Route Educational and Social Science Journal, 1(3), 214-229.

Şahin, T. Y., \& Yıldırım, S. (2004). Öğretim teknolojileri ve materyal geliştirme [Instructional technologies and material development]. Ankara: Anı Yayıncılık.

Saka, A. Z., \& Saka, A. (2005). Teacher candidates' level of development of their professional skills in instructional technologies and material development lesson: Sakarya sample. Sakarya University Journal of Education Faculty, 10, 81-177.

Sarıtaş, D., \& Polat, M. (2017). Removing of misconceptions related with some basic science concepts with purpose-built science teaching materials. Researcher: Social Science Studies, 5(10). 73-100.

Seferoğlu, S. (2006). Öğretim teknolojileri ve materyal tasarımı [Instructional technologies and material design]. Ankara: Pegem A Yayıncılık

Smith, P. L., \& Ragan, T. J. (2004). Instructional design (3 ${ }^{\text {rd }}$ Ed.). MA: John Wiley \& Sons.

Ünal, M., Akıncı, Ş., \& Şahin, F. (2000, October). Biyolojik kavramların öğretilmesinde modellerin rolü: mitoz bölünme [The role of models in teaching biological concepts: mitosis]. $4^{\text {th }}$ Science Education Congress, MEB Basımevi, Ankara.

Woodcock, S., \& Reupert, A. (2012). A cross-sectional study of student teachers' behaviour management strategies throughout their training years. The Australian Educational Researcher, 39(2), 159172.

Yalın, H. İ. (2004). Öğretim teknolojileri ve materyal geliştirme [Instructional technologies and material development] (13 ${ }^{\text {th }}$ Ed.). Ankara: Nobel Yayıncllık.

Yanpar, T. (2006). Teknoloji tabanlı eğitim [Technology-based education]. In V. Sönmez (Ed.), Ĕ̆itim bilimlerine giriş [Introduction to educational sciences] (pp. 187-212). Ankara: Anı Yayıncllı.

Yanpar, T., Koray, Ö., Parmaksız, R. Ş., \& Arslan, A. (2006). Investigation of hands-on and technology based materials prepared by preservice teachers with respect to the dimensions of creativity. Educational Administration: Theory and Practice, 45(45), 129-148.

Yelken, T. Y. (2009). The effects of materials development based on "creativity activities within a group" on teacher candidates' portfolios. Education and Science, 34(153), 83-94.

Yenen, E. T., \& Dursun, F. (2018). Examination of teacher candidates' opinions on ideal education environment. Journal of Social Sciences of Mus Alparslan University, 6(6) 1041-1049. https://doi.org/18506/anemon.421565

Yıldırım, A., \& Şimşek, H. (2013). Sosyal bilimlerde nitel araştırma yöntemleri [Qualitative research methods in the social sciences] (9 $9^{\text {th }}$ Ed.). Ankara: Seçkin Yayıncılık.

Yin, R. K. (2003). Case study research design and methods. London: Sage Publications.

Zedan, R. (2010). New dimensions in the classroom climate. Learning Environments Research, 13, 75-88. 


\section{Attachments}

Appendix-1: Instructional Technologies and Material Design course content

"Concepts related to instructional technology, features of various instructional technologies, the place and use of instructional technologies in the instructional process, determination of technology needs of school or class, making appropriate technology planning and execution, developing two and three dimensional materials through instructional technologies (developing worksheets, designing activities, overhead transparencies, slides, visual media (VCD, DVD) materials, computer-based tools), examination of educational software, evaluation of instructional materials in various qualities, internet and distance education, visual design principles, research on the effectiveness of teaching materials, the use of instructional technologies in Turkey and in the world" (CEH, 2007).

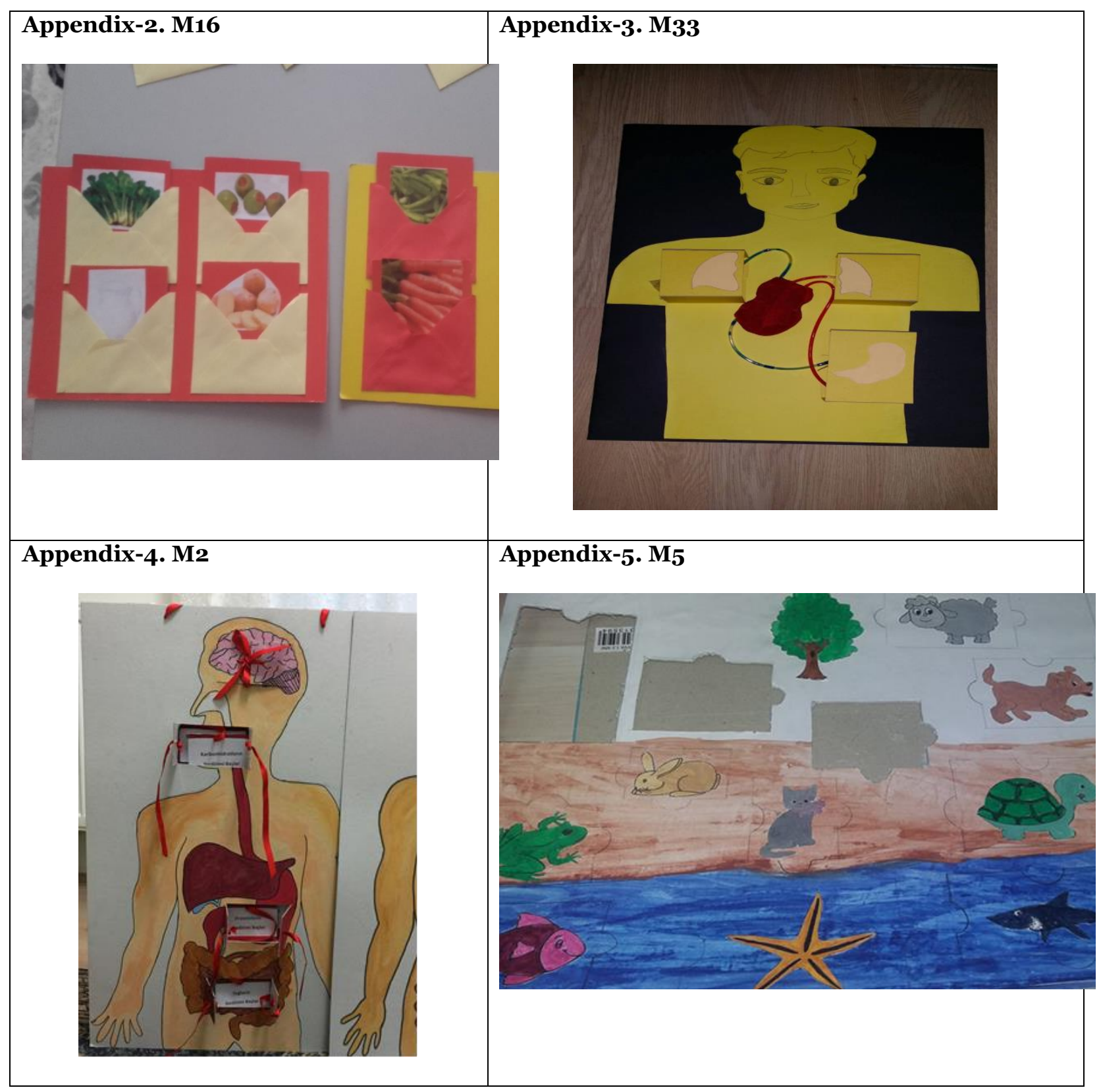


D. Saritaş \& E. T. Yenen - Science Teacher Candidates' Skills to Ensure Method-Material...

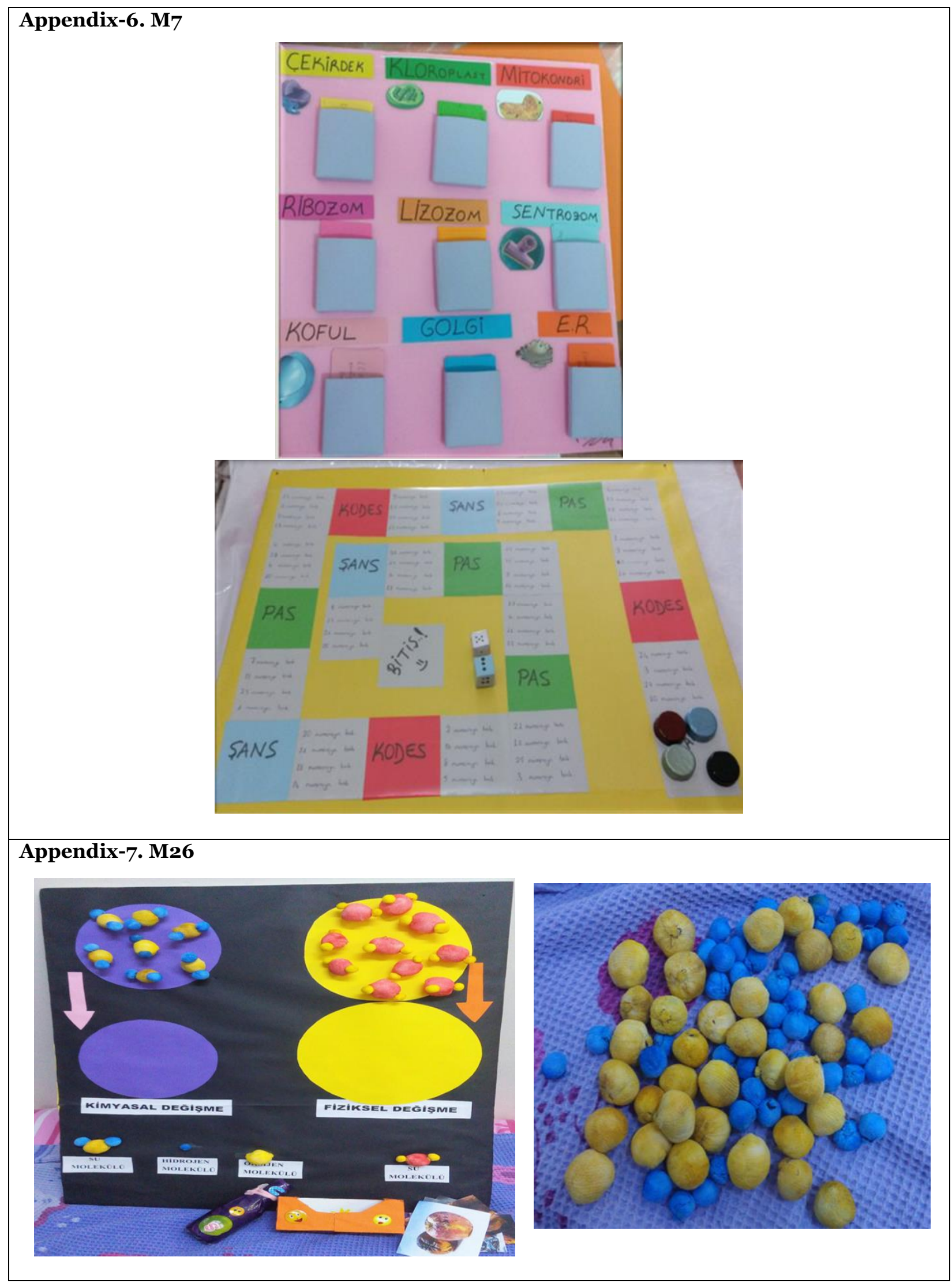




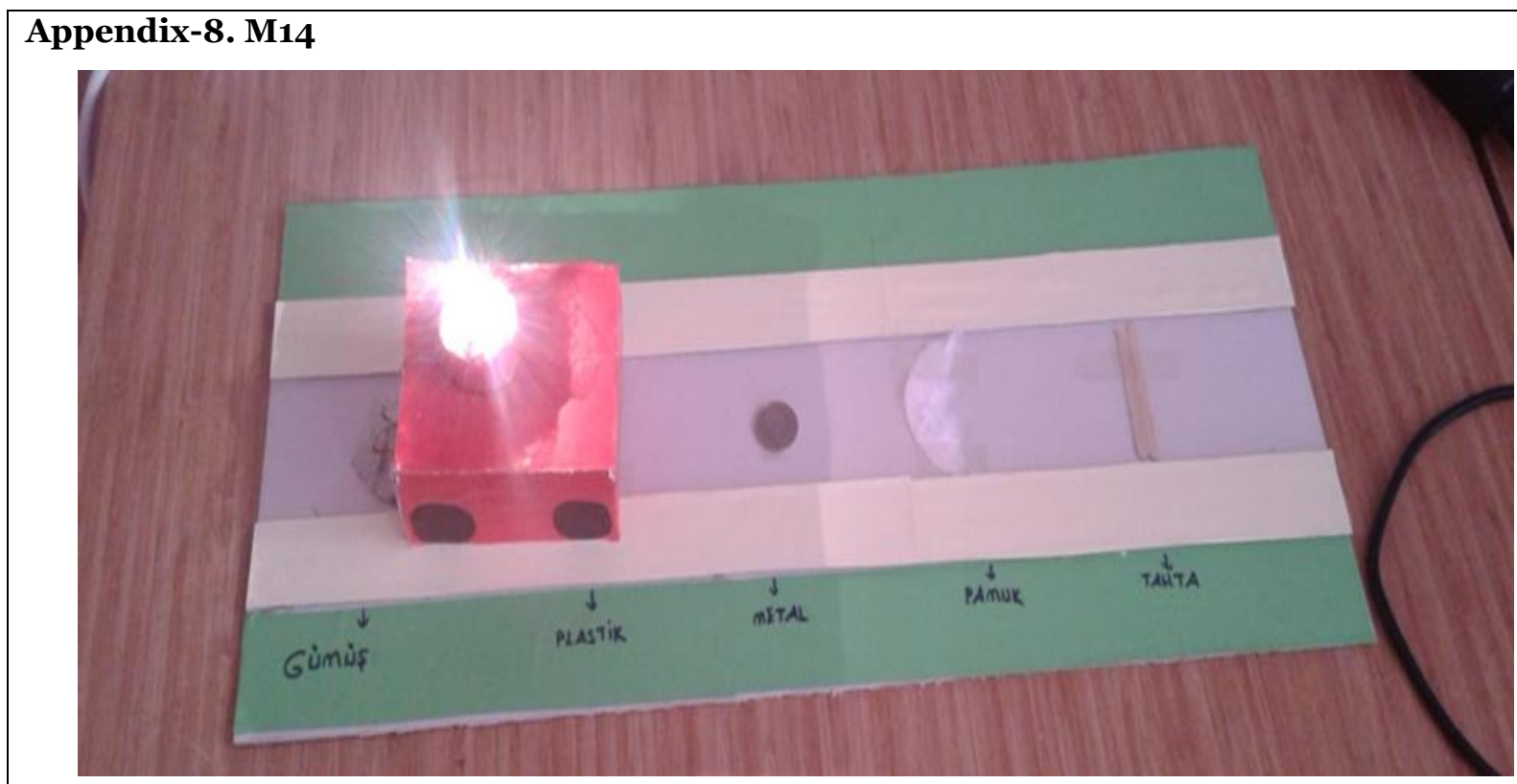

\section{Appendix-9. M-40}
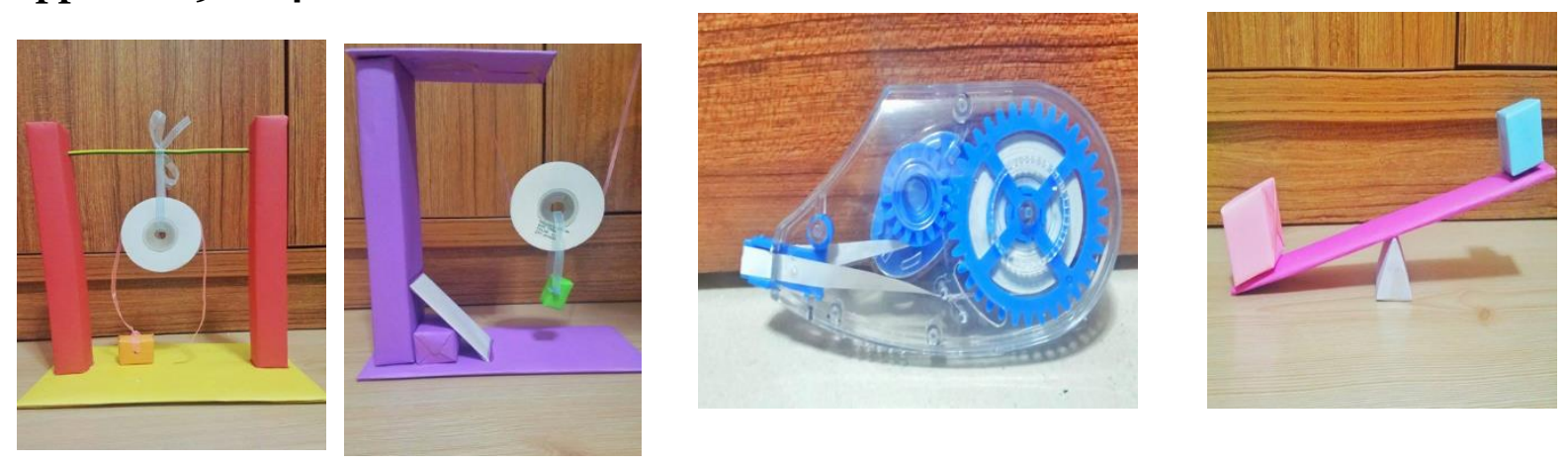

\section{Appendix-10. M13}
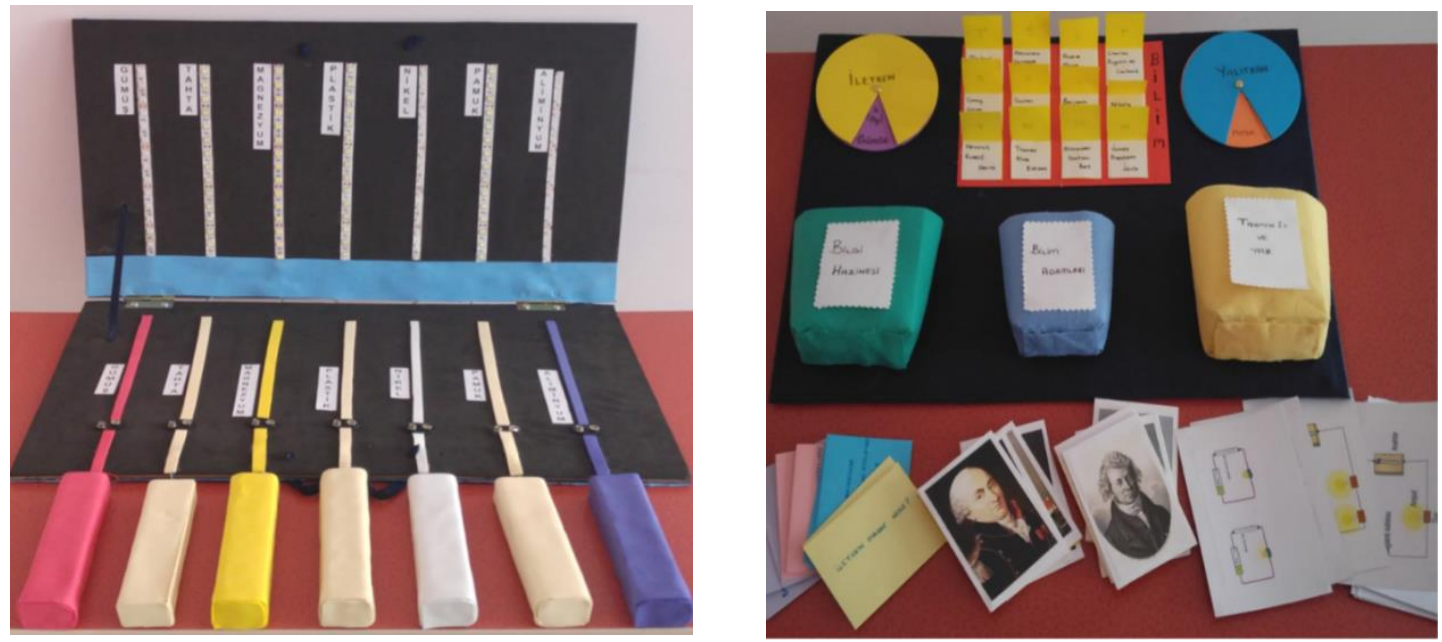
D. Saritaş \& E. T. Yenen - Science Teacher Candidates' Skills to Ensure Method-Material...

C O A $\mathrm{s}$ 